\title{
Expression changes in arrestin $\beta 1$ and genetic variation in catechol-O-methyltransferase are biomarkers for the response to morphine treatment in cancer patients
}

\author{
HIROMICHI MATSUOKA $^{1}$, TOKUZO ARAO ${ }^{2}$, CHIHIRO MAKIMURA $^{1}$, MASAYUKI TAKEDA $^{1}$, \\ HIDEMI KIYOTA $^{1}$, JUNJI TSURUTANI ${ }^{1}$, YOSHIHIKO FUJITA ${ }^{2}$, KAZUKO MATSUMOTO ${ }^{2}$, \\ HIDEHARU KIMURA ${ }^{2}$, MASATOMO OTSUKA ${ }^{3}$, ATSUKO KOYAMA ${ }^{4}$, CHIYO K. IMAMURA ${ }^{5}$, \\ YUSUKE TANIGAWARA $^{5}$, TAKEHARU YAMANAKA ${ }^{6}$, KYOKO TANAKA $^{7}$, \\ KAZUTO NISHIO $^{2}$ and KAZUHIKO NAKAGAWA ${ }^{1}$
}

\begin{abstract}
Departments of ${ }^{1}$ Medical Oncology and ${ }^{2}$ Genome Biology, Kinki University Faculty of Medicine, Osaka 589-8511; Departments of ${ }^{3}$ Palliative Care and ${ }^{4}$ Psychosomatic Medicine, Sakai Hospital, Kinki University Faculty of Medicine, Osaka 590-0132; ${ }^{5}$ Department of Clinical Pharmacokinetics and Pharmacodynamics, School of Medicine, Keio University, Tokyo 160-8582; ${ }^{6}$ Institute for Clinical Research, National Kyushu Cancer Center,

Fukuoka 811-1395; 7 Department of Oncology Nursing, School of Nursing, Osaka

Prefecture University, Habikino Campus, Osaka 583-8555, Japan
\end{abstract}

Received November 1, 2011; Accepted December 5, 2011

DOI: $10.3892 /$ or.2012.1660

\begin{abstract}
Genetic differences in individuals with regard to opioid-receptor signaling create clinical difficulties for opioid treatment; consequently, useful pharmacodynamic and predictive biomarkers are needed. In this prospective study, we studied gene expression changes in peripheral blood leukocytes using a microarray and real-time RT-PCR analysis to identify pharmacodynamic biomarkers for monitoring the effect of morphine in a cohort of opioid-treatment-naïve cancer patients. We also examined genetic variations in opioid receptor mu 1 $(O P R M 1,118 \mathrm{~A} \rightarrow \mathrm{G})$ and catechol-O-methyltransferase $(C O M T$, $472 \mathrm{G} \rightarrow \mathrm{A}$ ) to evaluate predictive biomarkers of the treatment outcome of morphine. The plasma concentration of morphine was measured using a liquid chromatography-tandem mass spectrometry method. Microarray analysis revealed that the mRNA expression levels of arrestin $\beta 1$ (ARRBl) were significantly down-regulated by morphine treatment. Real-time RT-PCR analysis against independent samples confirmed the results $(\mathrm{P}=0.003)$ and changes during treatment were negatively correlated with the plasma morphine concentration $(\mathrm{R}=-0.42)$. No correlation was observed between the genotype of OPRMI and morphine treatment; however, the plasma concentration
\end{abstract}

Correspondence to: Dr Kazuto Nishio, Department of Genome Biology, Kinki University School of Medicine, 377-2 Ohno-higashi, Osaka-Sayama, Osaka 589-8511, Japan

E-mail:knishio@med.kindai.ac.jp

Key words: arrestin, catechol-O-methyltransferase, morphine, microarray, opioid receptor $\mu 1$ of morphine and the required dose of morphine were significantly lower for the A/A genotype of $C O M T$ (vs. A/G+G/G, $\mathrm{P}=0.008$ and 0.03 ). We found that changes in the expression of $A R R B 1$ may be a novel pharmacodynamic biomarker and the COMT $472 \mathrm{G} \rightarrow \mathrm{A}$ genotype may be a predictive biomarker of the response to morphine treatment.

\section{Introduction}

Pharmacogenetic, pharmacokinetic and pharmacodynamic variations among individuals result in a wide variety of responses to pain sensation and to analgesics; therefore, intensive investigations of biomarkers for opioid treatment have been performed to improve the effectiveness of morphine treatment (1).

The opioid receptors are G-protein coupled receptors (GPCRs), and three types of receptors $\mu, \delta$ and $\kappa$-opioid receptors (OPRM1, OPRD1 and OPRK1) are known to serve as receptors for morphine (2). Among them, OPRMI generated the main analgesic effect induced by morphine in a knock-out study performed in mice (3). Agonists for opioid receptors induce the activation of GPCRs, triggering the activation of various downstream molecules (2). A regulator of the G-protein signaling (RGS)-protein family negatively regulates opioid-receptor signaling by accelerating the deactivation of G proteins, and the regulators RGS2 and RGS9 are thought to be involved in resistance to morphine (4-6). In addition, G-protein coupled receptor kinase (GRK) phosphorylates the opioid receptors, leading to the binding of arrestin $\beta 1$ and 2 (ARRB1 and 2) to the opioid receptors (7). Thus, GRKs and ARRBs negatively regulate opioid-receptor signaling and are thought to be involved in resistance to morphine $(8,9)$. To identify pharmacodynamic biomarkers that are capable 
of monitoring the drug effect, we examined the gene expression changes in opioid signaling-related molecules using a microarray and real-time RT-PCR analysis in peripheral blood leucocytes (PBLs).

Meanwhile, genetic variants associated with varying pain sensitivity and responses to morphine are thought to be potential biomarkers for predicting the outcome of morphine treatment $(1,10)$. In this study, we also evaluated two functional genetic variants, OPRM1 $118 \mathrm{~A} \rightarrow \mathrm{G}$ and catecholamine-Omethyltransferase gene $(C O M T) 472 \mathrm{G} \rightarrow \mathrm{A}$ (also known as Val158Met). The $118 \mathrm{~A} \rightarrow \mathrm{G}$ variant of $O P R M 1$ leads to a change in amino acids at position 40, affecting a putative glycosylation site of the receptor and biologically altering receptor activity (1). The enzyme activity of COMT is genetically defined as high in $\mathrm{G} / \mathrm{G}$, intermediate in G/A and low in $\mathrm{A} / \mathrm{A}$, and its genotype is thought to be associated with the effect of opioid-signaling (11).

In this prospective study, we examined gene expression to explore possible pharmacodynamic biomarkers and to evaluate the use of functional genetic variants as predictive biomarkers of the response to morphine treatment in a cohort of opioid-treatment-naïve cancer patients.

\section{Materials and methods}

Patients and samples. This prospective study was conducted between 2009 and 2011 at the Kinki University Faculty of Medicine and Sakai Hospital, Kinki University Faculty of Medicine. Clinicopathological features including age, gender, ECOG performance status (PS) and type of primary malignant neoplasm were recorded. Morphine treatment was performed according to the standard method including titration (NCCN Guidelines $^{\mathrm{TM}}$, Adult Cancer Pain). The required doses of morphine on Day 1 and on Day 8 are thought to be associated with the results of titration and the dose in the stationary phase, respectively.

PBL samples were obtained at baseline (pretreatment) and on Day 1 for the gene expression analyses. PBL samples for DNA were obtained at baseline. To measure the plasma concentrations of morphine, blood samples were collected on Days 1 and 8 . The separated plasma were stocked at $-80^{\circ} \mathrm{C}$ until use. The present study was approved by the institutional review boards of both centers and written informed consent was obtained from all the patients.

RNA extraction. Each 2.5-ml whole blood sample was stored in a PAX gene Blood RNA tube (Qiagen, Hilden, Germany). RNA was extracted according to the manufacturer's protocol (Qiagen). Then, massively containing globin mRNA was removed using a biotinylated Globin-capture oligonucleotides-based method and the GLOBINclear ${ }^{\mathrm{TM}}$ kit (Ambion, Austin, TX). The quality and quantity of RNA obtained from these samples were verified using a NanoDrop2000 spectrophotometer (Cole-Parmer, Vernon Hills, IL).

Real-time reverse transcription PCR. The methods used in this section have been previously described (12). GAPD was used to normalize the expression levels in the subsequent quantitative analyses. The primers used for real-time RT-PCR were purchased from Takara (Otsu, Japan) as follows: OPRMI forward, 5'-TCA ATG TCT GCA ACT GGA TCC TC-3' and reverse, 5'-CAC TGG CAT AAT GAA GGC GAA G-3'; OPRDI forward, 5'-CTG GGC AAC GTG CTT GTC A-3' and reverse, 5'-CAT CAG GTA CTT GGC ACT CTG GAA-3'; OPRK1 forward, 5'-CAC TTC ACG TGC TCT TAC AGC GTT A-3' and reverse, 5'-CCC TTG TGG GCA CAT ACA GCT AC-3'; ARRB1 forward, 5'-GAG AAC GAG ACG CCA GTA GAT ACC A-3' and reverse, 5'-GGC GAG CAA AGT CCT CAA ATA CA-3'; ARRB2 forward, 5'-ACC AAC CTG GCT TCC AGC A-3' and reverse, 5'-AAA GGC AGC TCC ACA GAG ACA TC-3'; GRK5 forward, 5'-GGA GCT GAA CGT GTT TGG ACC TA-3' and reverse, 5'-AGC TGG GCG AAC TCT TGG AA-3'; $R G S 9$ forward, 5'-GCA CAA ACC CAC ATT TAC ATG CTC-3' and reverse, 5'-GCT TTG GCC AGC ATG TCC TTA-3'; GAPD forward, 5'-GCA CCG TCA AGG CTG AGA AC-3' and reverse, 5'-ATG GTG GTG AAG ACG CCA GT-3'.

Microarray analysis. The microarray procedure was performed according to the Affymetrix protocols (Santa Clara, CA), as described previously (13). Briefly, cRNA was synthesized using the GeneChip ${ }^{\circledR}$ 3'-Amplification Reagents One-Cycle cDNA Synthesis Kit (Affymetrix). The labeled cRNAs were then purified and used for the construction of the probes. Hybridization was performed using the Affymetrix Gene Chip HG-U133 Plus 2.0 array for $16 \mathrm{~h}$ at $45^{\circ} \mathrm{C}$. The signal intensities were measured using a GeneChip ${ }^{\circledR}$ Scanner 3000 (Affymetrix) and converted to numerical data using GeneChip Operating Software, Ver. 1 (Affymetrix).

Genotyping. The genotype was evaluated for OPRM1 118A $\rightarrow \mathrm{G}$ (rs1799971, p.Asn40Asp) and COMT 472G $\rightarrow \mathrm{A}$ (rs4680, p.Val158Met). Genomic DNA isolated from blood samples using a QIAamp ${ }^{\circledR}$ DNA Blood Mini Kit (Qiagen) were amplified with the following primers: for OPRM1 forward, 5'-AAG TCT CGG TGC TCC TGG CTA CC-3' and reverse, 5'-GTT TCC GAA GAG CCC CAC CAC GC-3'; and for COMT forward, 5'-GAT TCA GGA GCA CCA GCC CTC C-3' and reverse (intronic), 5'-CAC TGA GGG GCC TGG TGA TAG TG-3'. Each PCR reaction was performed in a $20-\mu 1$ volume containing $20 \mathrm{ng}$ of template, $0.5 \mu \mathrm{M}$ of each primer, Ampdirect Plus (Shimadzu Corp., Kyoto, Japan) and 0.5 units of NovaTaq ${ }^{\mathrm{TM}}$ DNA Polymerase (Merck, Darmstadt, Germany). The amplification was performed for 35 cycles $\left(95^{\circ} \mathrm{C}\right.$ for $30 \mathrm{sec}, 60^{\circ} \mathrm{C}$ for $30 \mathrm{sec}$ and $72^{\circ} \mathrm{C}$ for $\left.45 \mathrm{sec}\right)$. The resulting PCR fragments consisting of $320 \mathrm{bp}$ (OPRMI) and 210 bp $(C O M T)$ were directly sequenced with the corresponding forward and reverse primers, respectively.

Measurement of plasma concentration of morphine. The plasma concentration of morphine was measured using a liquid chromatography-tandem mass spectrometry (LC-MS/ MS) method. Morphine was purchased from Daiichi Sankyo Co., Ltd. (Tokyo, Japan). Imipramine, an internal standard (IS), was obtained from Sigma-Aldrich (St. Louis, MO, USA). Pretreatment of the plasma samples was performed using protein precipitation. Briefly, $100 \mu \mathrm{l}$ of plasma was mixed with $250 \mu \mathrm{l}$ of IS solution ( $1 \mathrm{ng} / \mathrm{ml}$ imipramine in methanol). After vortexing (30 sec) and centrifugation (13,000 rpm, $5 \mathrm{~min})$, the supernatant was directly analyzed using an autosampler. An 
Table I. Clinical characteristics of study patients.

\begin{tabular}{|c|c|}
\hline Characteristics & No. of patients \\
\hline \multicolumn{2}{|l|}{ Age (years) } \\
\hline$<65$ & 14 \\
\hline$\geq 65$ & 34 \\
\hline \multicolumn{2}{|l|}{ Gender } \\
\hline Male & 25 \\
\hline Female & 23 \\
\hline \multicolumn{2}{|l|}{ PS } \\
\hline $0-2$ & 32 \\
\hline $3-4$ & 16 \\
\hline \multicolumn{2}{|l|}{ Tumor types } \\
\hline Lung cancer & 20 \\
\hline CRC & 8 \\
\hline Gastric cancer & 5 \\
\hline Others & 15 \\
\hline \multicolumn{2}{|c|}{ Required dose of morphine } \\
\hline \multicolumn{2}{|l|}{ Day 1} \\
\hline $20 \mathrm{mg}$ & 3 \\
\hline $30 \mathrm{mg}$ & 36 \\
\hline $60 \mathrm{mg}$ & 6 \\
\hline $90 \mathrm{mg}$ & 2 \\
\hline $\mathrm{NE}$ & 1 \\
\hline \multicolumn{2}{|l|}{ Day 8} \\
\hline $20 \mathrm{mg}$ & 5 \\
\hline $30 \mathrm{mg}$ & 20 \\
\hline $40 \mathrm{mg}$ & 1 \\
\hline $60 \mathrm{mg}$ & 9 \\
\hline $90 \mathrm{mg}$ & 1 \\
\hline $120 \mathrm{mg}$ & 1 \\
\hline $\mathrm{NE}$ & 11 \\
\hline
\end{tabular}

PS, performance status; CRC, colorectal cancer; Others, other primary tumor types; NE, not evaluated.

LC-MS/MS device was equipped with an Acquity UPLC (Ultra Performance LC) system and a Xevo TQ MS (Waters, Milford, MA, USA). Chromatographic separations were obtained under gradient conditions using an ACQUITY UPLC BEH C18 Column (100 mm x $2.1 \mathrm{~mm}$ ID, $1.7-\mu \mathrm{m}$ particle size; Waters). The mobile phase consisted of eluent $\mathrm{A}(10 \mathrm{mmol} / \mathrm{l}$ ammonium formate) and eluent B (methanol). The flow rate was $0.5 \mathrm{ml} /$ min and the gradient was from 2 to $60 \% \mathrm{~B}$ in $3.5 \mathrm{~min}$, then an increase to $98 \%$ B in $0.5 \mathrm{~min}$, holding at $98 \% \mathrm{~B}$ for $1 \mathrm{~min}$ and resetting to the initial conditions. The total run time was 8.5 min per sample. The column temperature was $45^{\circ} \mathrm{C}$, the sample temperature was $10^{\circ} \mathrm{C}$ and the injection volume was $5 \mu \mathrm{l}$. The retention times of morphine and imipramine (IS) were 1.69 and $4.31 \mathrm{~min}$, respectively. The mass spectrometer was operated in a positive electrospray mode. The capillary voltage was $0.5 \mathrm{kV}$ and the desolvation temperature was $500^{\circ} \mathrm{C}$.
The multiple reaction monitoring mode detected morphine and imipramine (IS) as follows: transitions, $286.4 \rightarrow 152.3$ and $281.2 \rightarrow 86.0$; cone voltages, 42 and $28 \mathrm{~V}$; collision energies, 48 and $16 \mathrm{~V}$, respectively. The chromatographic data were acquired and analyzed using MassLynx software, equipped with QuanLynx (Waters). Standard curves were prepared for a concentration range of $0.5-50 \mathrm{ng} / \mathrm{ml}$ for morphine. The inter- and intra-day variabilities in precision (expressed as the coefficient of variation) for morphine ranged from 4.2 to $7.7 \%$ and from 4.4 to $4.7 \%$, respectively. The average accuracies for morphine were between 100.4 and $106.1 \%$.

Statistical analysis. Differences between groups were analyzed using the Student's t-test or the Fisher's exact test. A P-value of $<0.05$ was considered statistically significant. All analyses were performed using JMP (SAS Institute, Cary, NC). A microarray analysis was performed using BRB-Array Tools software, Ver. 3.6.0 (http://linus.nci.nih.gov/BRB-ArrayTools. $\mathrm{html})$, as described previously $(13,14)$.

\section{Results}

Patient results. A total of 48 patients with opioid-treatment naïve and histologically confirmed malignant neoplasms who were scheduled to undergo opioid treatment were evaluated in this study (Fig. 1A). All 48 patients and a total of 96 samples (baseline and Day 1) were evaluated in the gene expression analysis. Forty-one patients and samples were evaluated in the genotype analysis because the DNA samples were insufficient in 7 cases. The plasma concentration of morphine was determined for 47 samples on Day 1 and for 43 samples on Day 8.

The patient characteristics are summarized in Table I. The median age was 69 years (40-85 years); 25 patients were men and 23 patients were women. Sixty-seven percent of the patients had a PS of $0-2$ and $42 \%$ had advanced lung cancer. The other primary tumors were 8 colorectal cancers, 5 gastric cancers, 4 unknown primary cancers, 2 pancreas cancers, 2 breast cancers, 2 gallbladder cancers, 1 renal cell carcinoma, 1 bladder cancer, 1 malignant lymphoma, 1 malignant pheochromocytoma and 1 skin cancer. The median required dose of morphine on Day 1 was $30 \mathrm{mg}(20-90 \mathrm{mg})$, while that on Day 8 was $30 \mathrm{mg}(20-120 \mathrm{mg})$.

Down-regulation of ARRBI $m R N A$ expression and morphine treatment. To identify pharmacodynamic biomarkers for monitoring the effect of morphine, we examined changes in gene expression during morphine treatment (baseline vs. Day 1) using a microarray analysis for 20 samples from 10 cases and validated the results using real-time RT-PCR for 76 samples from 38 cases, focusing on opioid receptor signaling. A schema for opioid receptor signaling is shown (Fig. 1B). The microarray analysis revealed that the mRNA expression levels of $A R R B 1$ and $G R K 5$ were significantly down-regulated by morphine treatment $(\mathrm{P}=0.01$ and 0.001 , Table II). Interestingly, down-regulated genes including ARRB1, GRK5 and RGS 9 $(\mathrm{P}=0.054)$ are known as negative regulators of opioid receptor signaling. The gene expressions of the opioid receptors were not changed. To confirm these results, we examined the gene expressions of these genes including OPRM1, OPRD1, 
A

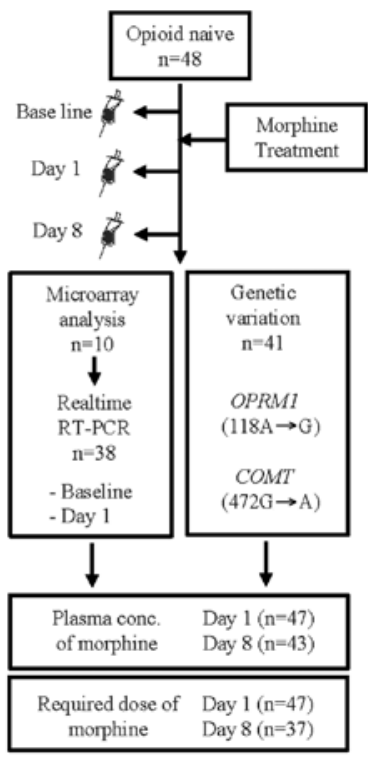

B

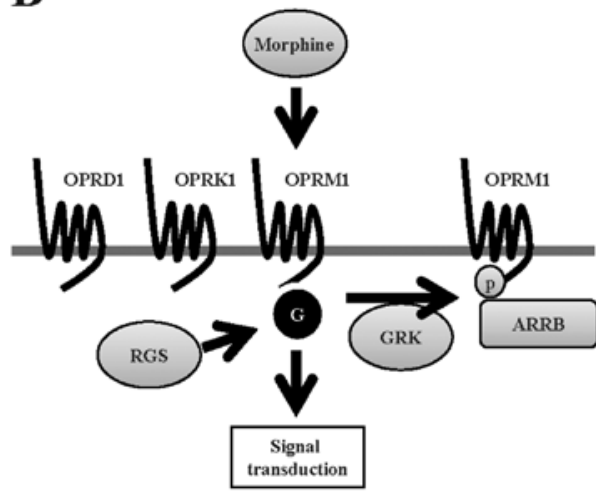

Figure 1. Schemas of study design and opioid receptor signaling. (A) Flow diagram of study. (B) Schema of opioid receptor signaling. OPRM1, D1 and K1 represent opioid receptor $\mu 1, \delta 1$ and $\kappa 1$, respectively; ARRB1 and 2 represent arrestin $\beta 1$ and 2; GRK, G protein-coupled receptor kinase; RGS, regulator of G-protein signaling; G, G protein; p, phosphorylation.

Table II. Gene expression changes in opioid signal-related molecules during morphine treatment.

\begin{tabular}{|c|c|c|c|c|c|c|c|}
\hline \multirow[b]{2}{*}{ Symbol } & \multirow[b]{2}{*}{ Name } & \multicolumn{2}{|c|}{ Microarray $(n=10)$} & \multirow[b]{2}{*}{ P-value } & \multicolumn{2}{|c|}{ Real-time RT-PCR (n=38) } & \multirow[b]{2}{*}{ P-value } \\
\hline & & Base line & Day 1 & & Base line & Day 1 & \\
\hline OPRMI & Opioid receptor, $\mu 1$ & $10.8 \pm 1.6$ & $10.9 \pm 1.4$ & 0.83 & $0.3 \pm 0.9$ & $1.4 \pm 7.9$ & 0.40 \\
\hline OPRDI & Opioid receptor, $\delta 1$ & $11.3 \pm 4.2$ & $10.0 \pm 0.0$ & 0.37 & $0.2 \pm 0.4$ & $0.3 \pm 1.4$ & 0.46 \\
\hline OPRK1 & Opioid receptor, $\kappa 1$ & $13.7 \pm 4.4$ & $12.6 \pm 3.5$ & 0.31 & $0.2 \pm 0.5$ & $0.2 \pm 0.3$ & 0.68 \\
\hline ARRBI & Arrestin $\beta 1$ & $123.7 \pm 40.2$ & $101.0 \pm 30.9$ & $0.01^{\mathrm{b}}$ & $48.6 \pm 18.1$ & $41.8 \pm 17.0$ & $0.003^{b}$ \\
\hline ARRB2 & Arrestin $\beta 2$ & $1193.5 \pm 476.5$ & $1158.3 \pm 317.6$ & 0.77 & $416.6 \pm 177.4$ & $430.9 \pm 164.3$ & 0.56 \\
\hline GRKl & G protein-coupled receptor kinase 1 & $10.3 \pm 1.3$ & $11.3 \pm 2.7$ & 0.36 & ND & ND & ND \\
\hline GRK4 & G protein-coupled receptor kinase 4 & $11.2 \pm 3.6$ & $10.9 \pm 2.5$ & 0.82 & ND & ND & ND \\
\hline GRK5 & G protein-coupled receptor kinase 5 & $419.6 \pm 121.1$ & $346.7 \pm 137.4$ & $0.001^{\mathrm{b}}$ & $14.9 \pm 6.9$ & $13.8 \pm 6.1$ & 0.12 \\
\hline GRK6 & G protein-coupled receptor kinase 6 & $464.4 \pm 87.5$ & $457.3 \pm 120.8$ & 0.87 & ND & ND & ND \\
\hline$R G S 2$ & Regulator of G-protein signaling 2 & $5776.5 \pm 1845.2$ & $5872.8 \pm 1847.0$ & 0.83 & ND & ND & ND \\
\hline$R G S 9$ & Regulator of G-protein signaling 9 & $26.7 \pm 16.5$ & $17.6 \pm 7.9$ & 0.05 & $2.8 \pm 2.4$ & $2.5 \pm 1.7$ & 0.17 \\
\hline
\end{tabular}

Gene expression changes were examined using microarray and real-time RT-PCR. Peripheral blood leukocytes sampled during morphine

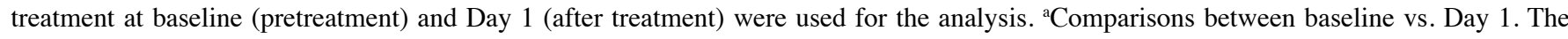
$\mathrm{P}$-values were calculated using a t-test. ${ }^{\mathrm{b}} \mathrm{P}<0.05$. Data are shown as the average \pm standard deviation.

OPRK1, ARRB1, ARRB2, GRK5 and RGS9 using real-time RT-PCR in 38 independent cases. The mRNA expression level of $A R R B 1$ was significantly and reproducibly down-regulated by morphine treatment ( $\mathrm{P}=0.003$, Table II and Fig. $2 \mathrm{~A})$. This result strongly suggests that $A R R B I$ may be a promising and pharmacodynamic biomarker of morphine.

Next, we evaluated whether the down-regulation of $A R R B I$ was correlated with the plasma concentration of morphine or the required dose. A moderate and weak inversed correlation was observed between the down-regulation of $A R R B 1$ and the plasma concentration of morphine $(\mathrm{R}=-0.42$, Fig. $2 \mathrm{~B})$ or the required dose of morphine $(R=-0.19$, Fig. $2 C)$. The results suggest that a higher plasma concentration or a higher dose of morphine induces the significant down-regulation of $A R R B 1$ and the change in $A R R B 1$ expression may be useful as a monitoring marker for morphine, although further studies are necessary.

COMT genotype is involved in outcome of morphine treatment. To find predictive biomarkers of the treatment outcome of morphine, we performed a functional genotype analysis 
A

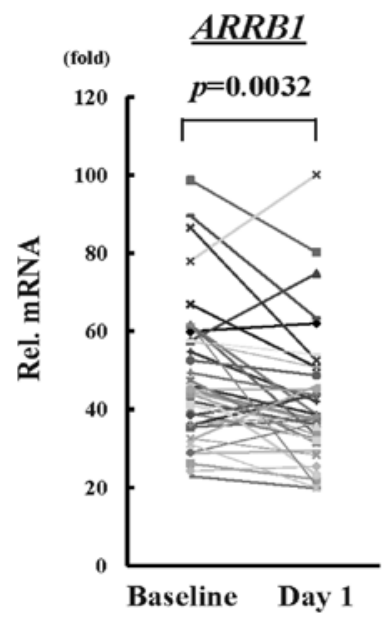

B

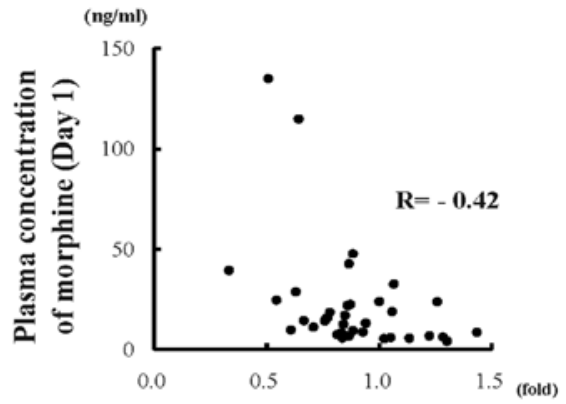

Expression change of $A R R B 1$

(Day 1 / Baseline)

C

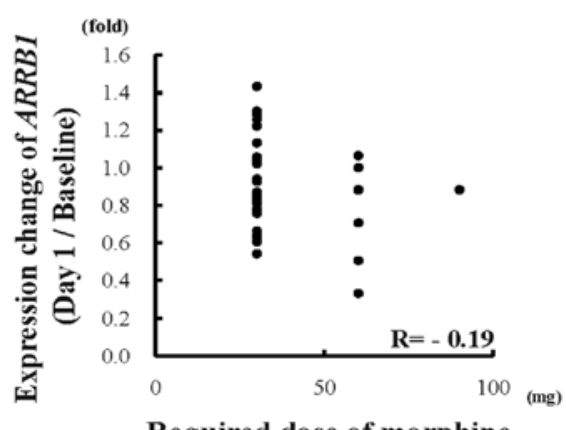

Required dose of morphine

(Day 1)

Figure 2. Down-regulation of arrestin $\beta 1$ (ARRB1) and outcome of morphine treatment. (A) A real-time RT-PCR analysis of peripheral blood leukocytes obtained at baseline (pretreatment) and on Day 1 showed that the mRNA level of $A R R B 1$ was significantly down-regulated during morphine treatment. Rel mRNA, normalized mRNA expression levels $\left(A R R B 1 / G A P D \times 10^{6}\right)$. (B) Expression changes in $A R R B 1$ and plasma concentration of morphine treatment on Day 1. R, correlation coefficient. (C) Expression changes of $A R R B 1$ and required dose of morphine on Day 1.

Table III. Genotypes and treatment outcome of morphine.

\begin{tabular}{|c|c|c|c|c|c|c|c|c|c|}
\hline \multirow[b]{2}{*}{ Symbol } & \multirow[b]{2}{*}{ Days } & \multicolumn{4}{|c|}{$O P R M 1118 \mathrm{~A} \rightarrow \mathrm{G}$} & \multicolumn{4}{|c|}{ COMT $472 \mathrm{G} \rightarrow \mathrm{A}$} \\
\hline & & $\mathrm{A} / \mathrm{A}$ & $\mathrm{A} / \mathrm{G}$ & $\mathrm{G} / \mathrm{G}$ & P-value ${ }^{a}$ & $\mathrm{G} / \mathrm{G}$ & G/A & $\mathrm{A} / \mathrm{A}$ & P-value \\
\hline \multirow{2}{*}{$\begin{array}{l}\text { Plasma concentration } \\
\text { of morphine ( } \mathrm{ng} / \mathrm{ml})\end{array}$} & D1 & $26.1 \pm 36.1$ & $21.0 \pm 23.2$ & $15.1 \pm 18.3$ & 0.45 & $34.1 \pm 35.7$ & $11.9 \pm 6.2$ & $8.7 \pm 4.0$ & $0.008^{c}$ \\
\hline & D8 & $28.0 \pm 20.0$ & $29.6 \pm 25.2$ & $28.1 \pm 22.2$ & 0.94 & $33.0 \pm 21.2$ & $23.1 \pm 23.2$ & $36.7 \pm 26.3$ & 0.56 \\
\hline \multirow{2}{*}{$\begin{array}{l}\text { Required dose of } \\
\text { morphine (mg) }\end{array}$} & D1 & $43.1 \pm 23.9$ & $32.2 \pm 9.0$ & $34.0 \pm 15.2$ & 0.78 & $43.7 \pm 21.4$ & $28.9 \pm 3.2$ & $30.0 \pm 0.0$ & $0.03^{\mathrm{c}}$ \\
\hline & D8 & $38.9 \pm 16.2$ & $37.1 \pm 15.4$ & $36.0 \pm 15.2$ & 0.82 & $40.0 \pm 15.4$ & $34.6 \pm 15.1$ & $40.0 \pm 17.3$ & 0.81 \\
\hline
\end{tabular}

Genotypes were evaluated for OPRM1 118A $\rightarrow \mathrm{G}(\mathrm{rs} 1799971$, p.Asn40Asp) and COMT 472G $\rightarrow \mathrm{A}(\mathrm{rs} 4680$, p.Val158Met). The treatment outcome of morphine was examined using the plasma concentration of morphine (Days 1 and 8) and the required dose of morphine (Days 1 and 8). ${ }^{\mathrm{a} C}$ Comparisons between $\mathrm{G} / \mathrm{G}$ vs. A/A+A/G of the OPRM1. ${ }^{\mathrm{b}}$ Comparisons between A/A vs. G/G+G/A of COMT. The P-values were calculated using a t-test. ${ }^{\mathrm{C}} \mathrm{P}<0.05$. Data are shown as the average \pm standard deviation.

of $O P R M 1118 \mathrm{~A} \rightarrow \mathrm{G}(\mathrm{rs} 1799971, \mathrm{p}$. Asn40Asp) and COMT $472 \mathrm{G} \rightarrow \mathrm{A}$ (rs4680, p.Val158Met). The treatment outcome of morphine was examined based on the plasma concentration of morphine (Days 1 and 8) and the required dose (Days 1 and 8) according to genotype. No correlation was observed between the OPRMI 118A $\rightarrow$ G genotype and the plasma concentration or the required dose of morphine (Table III). However, the plasma morphine concentration on Day 1 was significantly lower in patients with the A/A genotype of COMT, compared with those with the $\mathrm{A} / \mathrm{G}+\mathrm{G} / \mathrm{G}$ genotypes $(\mathrm{A} / \mathrm{A}: \mathrm{n}=4,8.7 \pm 4.0 \mathrm{ng} / \mathrm{ml}$; G/A: $\mathrm{n}=18,11.9 \pm 6.2 \mathrm{ng} / \mathrm{ml} ; \mathrm{G} / \mathrm{G}: \mathrm{n}=19,34.1 \pm 35.7 \mathrm{ng} / \mathrm{ml} ; \mathrm{P}=0.008$, Fig. 3A). In addition, the required dose of morphine on Day 1 was also significantly lower for the A/A genotype of COMT, compared with the $\mathrm{A} / \mathrm{G}+\mathrm{G} / \mathrm{G}$ genotypes $(\mathrm{A} / \mathrm{A}, 30.0 \pm 0.0 \mathrm{mg}$; G/A, 28.9 $\pm 3.2 \mathrm{mg} ; \mathrm{G} / \mathrm{G}, 43.7 \pm 21.4 \mathrm{mg}$; P=0.03, Fig. 3B). On the other hand, the genotype was not correlated with the treatment outcome of morphine on Day 8. Collectively, our results indicate that the COMT genotype is involved in the outcome of morphine treatment, suggesting that it may be useful as a predictive biomarker for morphine treatment. 
A

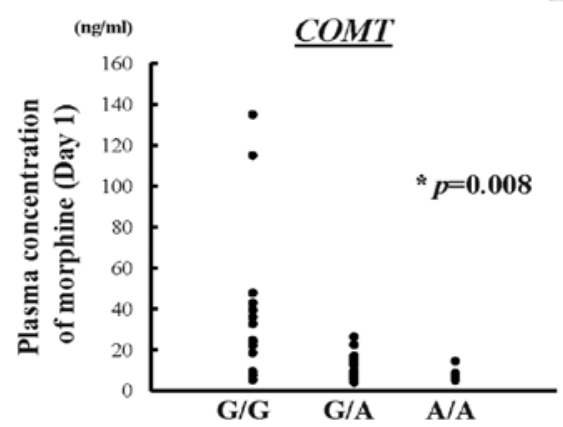

B

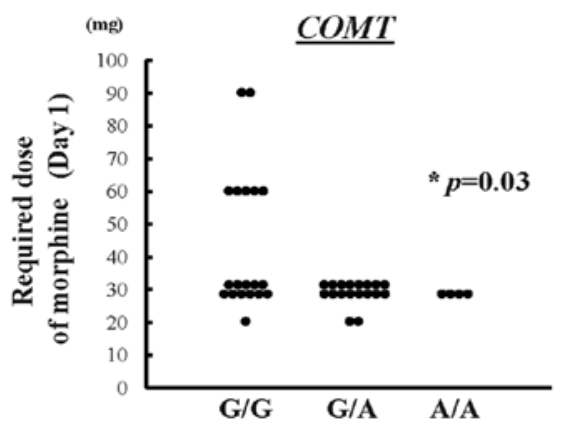

Figure 3. Catechol-O-methyltransferase genotypes (COMT 472G $\rightarrow$ A, rs4680, p.Val158Met) and outcome of morphine treatment. (A) Genotypes and plasma concentration of morphine treatment on Day $1 .{ }^{*}$ Comparisons between A/A vs. G/G+G/A of COMT. (B) Genotypes and required dose of morphine on Day 1 .

\section{Discussion}

Morphine activates opioid receptor signaling in the cells of the central nervous system (CNS). Unlike easily available tissues, such as blood cells, these CNS cells cannot be sampled and used for analysis; therefore, clinically useful pharmacodynamic biomarkers of morphine have remained largely unclear to date. We recently described an approach examining PBLs as surrogate tissues to evaluate drug response and found that it is a feasible, non-invasive and repeatable pharmacodynamic approach in clinical settings (15). In this study, we found that $A R R B 1 \mathrm{mRNA}$ expression is a reproducible and useful biomarker for monitoring the effects of morphine treatment using PBLs as surrogate tissues.

ARRB1 regulates the desensitization of numerous GPCRs including OPRM1, D1 and D2 dopamine receptors and emerging evidence has demonstrated that ARRB1 functions as a scaffold protein that links GPCRs to intracellular signaling, such as MAPK and as a transcription factor that translocates to the nucleus $(16,17)$. A recent study showed that chronic morphine treatment blocked the agonist-induced redistribution of ARRB1 in stably OPRM1-transfected HEK293 cells through the persistent stimulation of MAPK activity and the authors concluded that chronic morphine treatment produces adaptational changes at the ARRBI level (18). These observations and our findings suggest that the drug response of PBLs to morphine mediates the down-regulation of $A R R B I$ expression during morphine treatment and reflects the overall cellular response to opioid signaling in an individual.

COMT is one of the enzymes that inactivate catecholamines; therefore, it is regarded as key regulator of adrenergic, noradrenergic and dopaminergic signaling (19). Various diseases are thought to be involved in COMT function including mental disorders, suicidal behavior and personality traits, and tardive dyskinesia (11,21-23). Regarding the COMT genotype as it relates to cancer pain, individuals with a A/A (Met/Met) genotype had a lower regional opioid signal response to pain and a higher sensitivity to pain, compared with heterozygous individuals (24). On the other hand, several clinical studies have demonstrated that the required dose of morphine was lower in subjects with an A/A genotype of COMT, compared with others (25-27). These results are consistent with our result. The question why the required dose of morphine is lower in patients with an A/A genotype, even though they are more sensitive to pain, can be explained by a possibly elevated density of OPRM1 in patients with the A/A genotype (28). Our results indicate that $C O M T 472 \mathrm{G} \rightarrow \mathrm{A}$ may be a predictive biomarker, although further studies are necessary.

Taken together, our results may provide novel insights into the relations between morphine treatment and $A R R B I$ expression and the COMT $472 \mathrm{G} \rightarrow \mathrm{A}$ genotype.

\section{Acknowledgements}

This study was supported by the Third-Term Comprehensive 10-Year Strategy for Cancer Control and a Grant-in-Aid for Cancer Research from the Ministry of Health, Labour and Welfare (H22-037). We thank Mrs. Tomoko Kitayama, Mrs. Erina Hatashita, Mrs. Kiyoko Kuwata, Mrs. Haruka Yamaguchi, Mr. Hiromasa Wadaguri and Mrs. Akiko Mizumoto for their technical assistance. We also thank Dr Richard Simon and Dr Amy Peng for providing us with the BRB ArrayTools software.

\section{References}

1. Lötsch J, Geisslinger G and Tegeder I: Genetic modulation of the pharmacological treatment of pain. Pharmacol Ther 124: 168-184, 2009.

2. Marie N, Aguila B and Allouche S: Tracking the opioid receptors on the way of desensitization. Cell Signal 18: 1815-1833, 2006.

3. Matthes HW, Maldonado R, Simonin F, Valverde O, Slowe S, Kitchen I, Befort K, Dierich A, Le Meur M, Dollé P, Tzavara E, Hanoune J, Roques BP and Kieffer BL: Loss of morphineinduced analgesia, reward effect and withdrawal symptoms in mice lacking the mu-opioid-receptor gene. Nature 383: 819-823, 1996.

4. Neubig RR and Siderovski DP: Regulators of G-protein signalling as new central nervous system drug targets. Nat Rev Drug Discov 1: 187-197, 2002.

5. Garzón J, Rodríguez-Díaz M, López-Fando A and SánchezBlázquez P: RGS9 proteins facilitate acute tolerance to mu-opioid effects. Eur J Neurosci 13: 801-811, 2001.

6. Potenza MN, Gold SJ, Roby-Shemkowitz A, Lerner MR and Nestler EJ: Effects of regulators of $G$ protein-signaling proteins on the functional response of the mu-opioid receptor in a melanophore-based assay. J Pharmacol Exp Ther 291: 482-491, 1999.

7. Freedman NJ and Lefkowitz RJ: Desensitization of G proteincoupled receptors. Recent Prog Horm Res 51: 319-351, 1996. 
8. Ueda $\mathrm{H}$, Inoue $\mathrm{M}$ and Matsumoto T: Protein kinase $\mathrm{C}$-mediated inhibition of mu-opioid receptor internalization and its involvement in the development of acute tolerance to peripheral mu-agonist analgesia. J Neurosci 21: 2967-2973, 2001

9. Whistler JL, Chuang HH, Chu P, Jan LY and von Zastrow M: Functional dissociation of mu opioid receptor signaling and endocytosis: implications for the biology of opiate tolerance and addiction. Neuron 23: 737-746, 1999.

10. Tremblay $\mathbf{J}$ and Hamet P: Genetics of pain, opioids, and opioid responsiveness. Metabolism 59 (Suppl 1): S5-S8, 2010.

11. Hosák L: Role of the COMT gene Val158Met polymorphism in mental disorders: a review. Eur Psychiatry 22: 276-281, 2007.

12. Matsumoto K, Arao T, Tanaka K, Kaneda H, Kudo K, Fujita Y Tamura D, Aomatsu K, Tamura T, Yamada Y, Saijo N and Nishio K: mTOR signal and hypoxia-inducible factor- $1 \alpha$ regulate CD133 expression in cancer cells. Cancer Res 69 7160-7164, 2009.

13. Kaneda H, Arao T, Tanaka K, Tamura D, Aomatsu K, Kudo K, Sakai K, De Velasco MA, Matsumoto K, Fujita Y, Yamada Y, Tsurutani J, Okamoto I, Nakagawa $\mathrm{K}$ and Nishio K: FOXQ1 is overexpressed in colorectal cancer and enhances tumorigenicity and tumor growth. Cancer Res 70: 2053-2063, 2010.

14. Yamada Y, Arao T, Gotoda T, Taniguchi H, Oda I, Shirao K, Shimada Y, Hamaguchi T, Kato K, Hamano T, Koizumi F, Tamura T, Saito D, Shimoda T, Saka M, Fukagawa T, Katai H, Sano T, Sasako M and Nishio K: Identification of prognostic biomarkers in gastric cancer using endoscopic biopsy samples. Cancer Sci 99: 2193-2199, 2008.

15. Okamoto I, Kaneda H, Satoh T, Okamoto W, Miyazaki M, Morinaga R, Ueda S, Terashima M, Tsuya A, Sarashina A Konishi K, Arao T, Nishio K, Kaiser R and Nakagawa K: Phase I safety, pharmacokinetic, and biomarker study of BIBF 1120, an oral triple tyrosine kinase inhibitor in patients with advanced solid tumors. Mol Cancer Ther 9: 2825-2833, 2010.

16. Gainetdinov RR, Premont RT, Bohn LM, Lefkowitz RJ and Caron MG: Desensitization of $G$ protein-coupled receptors and neuronal functions. Annu Rev Neurosci 27: 107-144, 2004.
17. Ma L and Pei G: $\beta$-arrestin signaling and regulation of transcription. J Cell Sci 120: 213-218, 2007.

18. Eisinger DA, Ammer $\mathrm{H}$ and Schulz R: Chronic morphine treatment inhibits opioid receptor desensitization and internalization. J Neurosci 22: 10192-10200, 2002.

19. Domschke K and Deckert J: Genetics. Curr Top Behav Neurosci 2: 63-75, 2010.

21. Xu K, Ernst M and Goldman D: Imaging genomics applied to anxiety, stress response, and resiliency. Neuroinformatics 4: 51-64, 2006.

22. Calati R, Porcelli S, Giegling I, et al: Catechol-O-methyltransferase gene modulation on suicidal behavior and personality traits: review, meta-analysis and association study. J Psychiatr Res 45: 309-321, 2011.

23. Zai CC, Tiwari AK, Müller DJ, et al: The catechol-O-methyltransferase gene in tardive dyskinesia. World J Biol Psychiatry 11: 803-812, 2010.

24. Zubieta JK, Heitzeg MM, Smith YR, et al: COMT val158met genotype affects mu-opioid neurotransmitter responses to a pain stressor. Science 299: 1240-1243, 2003.

25. Rakvåg TT, Ross JR, Sato H, Skorpen F, Kaasa S and Klepstad P: Genetic variation in the catechol-O-methyltransferase (COMT) gene and morphine requirements in cancer patients with pain. Mol Pain 4: 64, 2008.

26. Reyes-Gibby CC, Shete S, Rakvåg T, Bhat SV, Skorpen F, Bruera E, Kaasa S and Klepstad P: Exploring joint effects of genes and the clinical efficacy of morphine for cancer pain: OPRM1 and COMT gene. Pain 130: 25-30, 2007.

27. Rakvåg TT, Klepstad P, Baar C, Kvam TM, Dale O, Kaasa S, Krokan HE and Skorpen F: The Val158Met polymorphism of the human catechol-O-methyltransferase (COMT) gene may influence morphine requirements in cancer pain patients. Pain 116: 73-78, 2005 . 